IRA-International Journal of Education \& Multidisciplinary Studies ISSN 2455-2526; Vol.05, Issue 03 (2016)

Pg. no. 153-160

Institute of Research Advances

http://research-advances.org/index.php/IJEMS

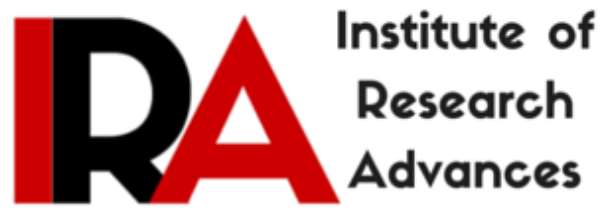

\title{
Pollution and Other Dimensions of Non- Renewable Groundwater in Haryana (India)
}

\section{Dr. Avtar Singh Rahi}

(M.Sc. NET M.Phil. Ph.D. M.Ed. Ph.D. MBA PGDHRM PGDJ)

Head and Associate Professor,

Department of Chemistry, Government Post-Graduate College,

Ambala Cantt.-133001, Haryana - India.

Type of Review: Peer Reviewed.

DOI: http://dx.doi.org/10.21013/jems.v5.n3.p3

\section{How to cite this paper:}

Rahi, A. (2016). Pollution and Other Dimensions of Non-Renewable Groundwater in Haryana (India). IRA International Journal of Education and Multidisciplinary Studies (ISSN 2455-2526), 5(3), 153-160. doi:http://dx.doi.org/10.21013/jems.v5.n3.p3

(C) Institute of Research Advances

\section{(c) EY-No}

This work is licensed under a Creative Commons Attribution-Non Commercial 4.0 International License subject to proper citation to the publication source of the work.

Disclaimer: The scholarly papers as reviewed and published by the Institute of Research Advances (IRA) are the views and opinions of their respective authors and are not the views or opinions of the IRA. The IRA disclaims of any harm or loss caused due to the published content to any party. 


\section{ABSTRACT}

The vital role groundwater plays as a decentralized source of drinking water for millions rural and urban families cannot be overstated. In India, where groundwater is used intensively for irrigation and industrial purposes, a variety of land and water-based human activities are causing pollution of this precious resource. There are no estimates of the public health consequences of groundwater pollution as it involves methodological complexities and logistical problems. The groundwater behavior in the Indian sub-continent is highly complicated due to the occurrence of diversified geological formations with considerable litho-logical and chronological variations, complex tectonic framework, climato-logical dissimilarities and various hydro-chemical conditions. Once contamination starts, very little can be done to check it except a total ban on pumping. But this is very difficult, as millions of rural families in India depend on groundwater for sustaining irrigated agriculture and livelihoods. Manufacturing and service industries have high demands for cooling water, processing water and water for cleaning purposes. Groundwater pollution occurs when used water is returned to the hydrological cycle. Haryana is fast emerging as one of the most favoured investment destinations in India. The State has taken lead in terms of planned industrial and urban growth compared to neighboring States, which has resulted in development of vibrant urban and industrial complexes. They dump the wastes in the rivers which results in water pollution. Management of groundwater resources in the Indian context is an extremely complex proposition as it deals with the interactions between the human society and the physical environment. Unplanned depletion of non-renewable groundwater reserves can undermine and potentially erode the economic and social vitality of any community. Hence, there is need to plan the exploitation of nonrenewable groundwater resources and guide their utilization with a view to making communities better prepared socio-economically to cope with increasing water stress as aquifer storage is depleted.

Keywords: Groundwater, Stress, Industrial, Pollution, Contamination, Resource, Depleting, Problem, Drinking, Effects, Community, Investment, Water-based, Health.

\section{INTRODUCTION}

The vital role groundwater plays as a decentralized source of drinking water for millions rural and urban families cannot be overstated. In India, where groundwater is used intensively for irrigation and industrial purposes, a variety of land and water-based human activities are causing pollution of this precious resource. There are no estimates of the public health consequences of groundwater pollution as it involves methodological complexities and logistical problems. The potential biological and toxicological effects of using contaminated water are dangerous. Prolonged exposure to water containing salts can cause kidney stone, yellowing of teeth, damaged joints and bone deformities, depressions in DNA and RNA synthesis, genotoxic effects, impairment of brain functions, neurological disorders, retardation of growth, abortion, disruption of the endocrine system, including ageing, liver damage, cancer, etc. The groundwater-resource challenge of the future is more complex; it is not only water allocation among irrigation, industry and municipalities but involves difficult decisions for balancing green and blue water for food, nature and society. Water governance is to provide water for human activities while paying attention to safeguarding the water of vital ecosystems, aquatic as well as terrestrial, not only as a means of preserving ecological functions (King et al. 2003) but as a strategy for resilience building when faced with such extreme events as floods, droughts and desertification phenomenon (Calder 2004).

\section{ISSUES IN TACKLING GROUNDWATER CONTAMINATION AND POLLUTION}

The groundwater behavior in the Indian sub-continent is highly complicated due to the occurrence of diversified geological formations with considerable litho-logical and chronological variations, complex tectonic framework, climato-logical dissimilarities and various hydro-chemical conditions. Integration of data on water quality and water supplies is very important from the point of view of assessing water availability for meeting various social, economic and environmental objectives. It is very difficult process to evolve measures to prevent and cure groundwater quality deterioration and 
generate reliable and accurate information through water quality monitoring to understand the actual source/cause, type and level of contamination because the technology involves expensive and sophisticated equipments that are difficult to operate and maintain and require substantial expertise in collecting, analyzing and managing data. India is too poor to afford some of the technologies that are successfully tried out in the West, especially United States because they are prohibitively expensive. The unplanned and non-scientific development of groundwater resources (mostly by individual initiatives) has led to an increasing stress. The adverse impacts can be observed in the form of long-term decline of groundwater levels, de-saturation of aquifer zones, increased energy consumption for lifting water from progressively deeper levels and quality deterioration due to saline water intrusion in coastal areas in different parts of the country. Once contamination starts, very little can be done to check it except a total ban on pumping. But this is very difficult, as millions of rural families in India depend on groundwater for sustaining irrigated agriculture and livelihoods. While nitrate pollution can be properly controlled through following recommended dosage of fertilizers, crop rotation, proper timing of fertilizer application and use of organic manure instead of chemical fertilizers, there are no institutional regimes governing fertilizer use and dumping of animal waste and Industrial pollution.

\section{INDUSTRIAL POLLUTION}

Manufacturing and service industries have high demands for cooling water, processing water and water for cleaning purposes. Groundwater pollution occurs when used water is returned to the hydrological cycle. Modern economic activity requires transportation and storage of material used in manufacturing, processing and construction. The disposal of wastes associated with the above activities contributes to groundwater contamination. Some businesses, usually without access to sewer systems, rely on shallow underground disposal. They use cesspools or dry holes, or send the wastewater into septic tanks. Any of these forms of disposal can lead to contamination of underground sources of drinking water. Dry holes and cesspools introduce wastes directly into the ground. Septic systems cannot treat industrial wastes. Wastewater disposal practices of certain types of businesses, such as automobile service stations, dry cleaners, electrical component or machine manufacturers, photo processors, and metal platters or fabricators are of particular concern because the waste they generate is likely to contain toxic chemicals. Other industrial sources of contamination include cleaning off holding tanks or spraying equipment on the open ground, disposing of waste in septic systems or dry wells, and storing hazardous materials in uncovered areas or in areas that do not have pads with drains or catchment basins. Underground and above ground storage tanks holding petroleum products, acids, solvents and chemicals can develop leaks from corrosion, defects, improper installation or mechanical failure of the pipes and fittings. Mining of fuel and non-fuel minerals can create many opportunities for groundwater contamination. The problems stem from the mining process itself, disposal of wastes, and processing of the ores and the wastes it creates. 


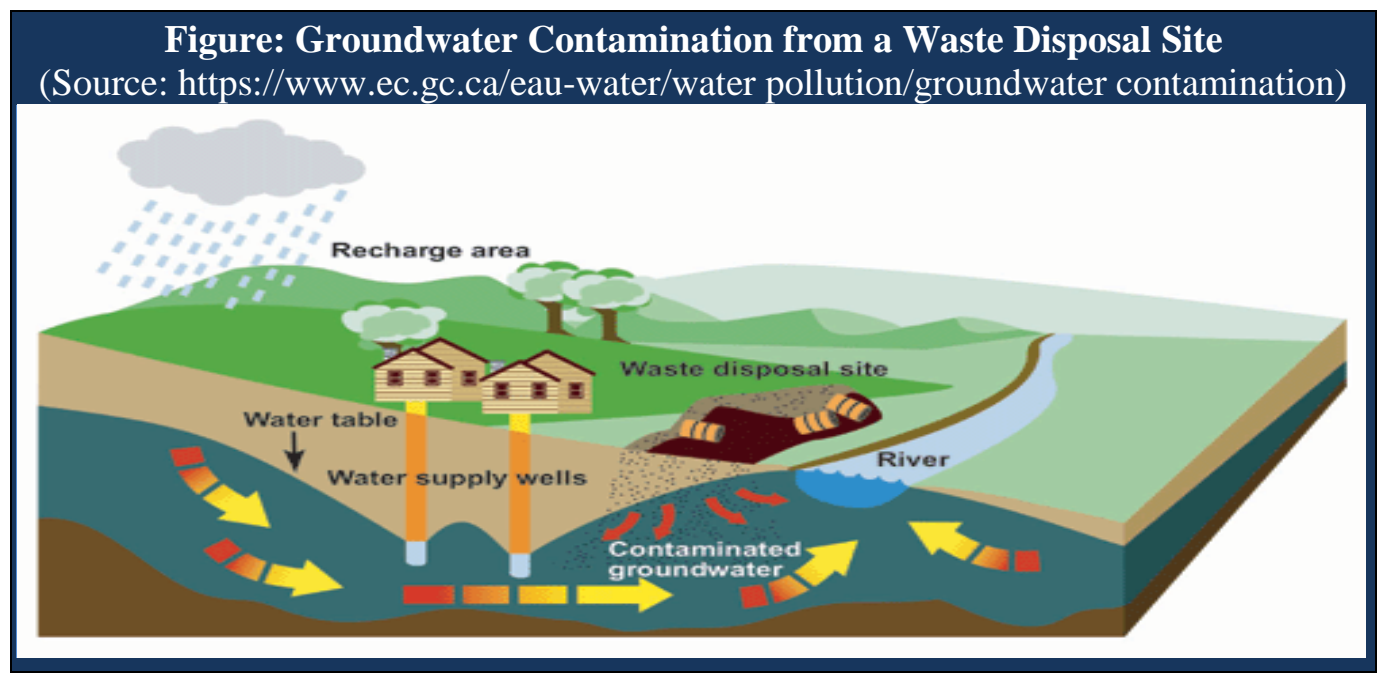

HARYANA - THE AREA UNDER STUDY

Haryana, the $20^{\text {th }}$ state of India, came into existence on $1^{\text {st }}$ November 1966 and presently has 21 districts. Haryana is one of the wealthier states of India and had the second highest per capita income in the country. Haryana is also one of the most economically developed regions in South Asia and its agricultural and manufacturing industries have experienced sustained growth since the 1970s. Haryana's main seasonal river, the Ghaggar rises in the outer Himalayas, between the Yamuna and the Satluj and enters the state near Pinjore in the Panchkula district. Passing through Ambala and Sirsa, it reaches Bikaner in Rajasthan and runs for $460 \mathrm{~km}$ before disappearing into the deserts of Rajasthan.

Table: Haryana at a Glance

(Source: MSME-Development Institute, Government of India, Ministry of MSME, msmedikarnal.gov.in)

\begin{tabular}{|l|l|c|c|c|c|}
\hline Item & Unit & $\mathbf{1 9 6 6 - 6 7}$ & $\mathbf{1 9 7 1 - 7 2}$ & $\mathbf{2 0 1 0 - 1 1}$ & $\mathbf{2 0 1 1 - 1 2}$ \\
\hline Geographical Area & Sq. kms. & - & 44,222 & - & 44,212 \\
\hline Population & Lacs & - & 100.37 & - & 253.53 \\
\hline Production of food-grains & Lac Tons & 25.92 & - & 166.29 & - \\
\hline Consumption of Fertilizers & Lac Tons & 0.13 & - & 13.6 & - \\
\hline Per hectare Consumption of Fertilizers & Kg & 2.9 & - & 209.8 & - \\
\hline Sugar Mills & - & 2 & - & - & 11 \\
\hline Milk Plants & - & 1 & - & - & 5 \\
\hline Schools & - & 5779 & & & 22762 \\
\hline Colleges (all types) & - & 52 & - & - & 1306 \\
\hline University & - & 1 & - & - & 23 \\
\hline Electricity Availability & Lac units per day & 15 & - & - & 1045 \\
\hline Tube wells Energized & - & 20190 & - & - & 531848 \\
\hline Area under Forests & Sq. kms. & 1362 & - & - & 1594 \\
\hline Villages covered by drinking water facilities & - & 170 & - & - & 7385 \\
\hline Houses Constructed & - & - & 500 & - & 66190 \\
\hline Hospitals/Dispensaries & - & 797 & - & - & 3902 \\
\hline Fleet strength of Roadways & - & 475 & - & - & 3469 \\
\hline Length of metallic roads & Kms. & 5100 & - & - & 38499 \\
\hline Area irrigated by canals & Lac hects. & 13.25 & - & 20.82 & - \\
\hline No. of tube-wells \& pumping sets & Lacs & 0.28 & - & - & 6.97 \\
\hline Industrial Units & - & 4681 & - & - & 83605 \\
\hline No. of tourist complexes & - & 1 & - & - & 43 \\
\hline
\end{tabular}


The total geographical area of the state is $4.42 \mathrm{mha}$, which is $1.4 \%$ of the geographical area of the country. The cultivable area is $3.7 \mathrm{mha}$, which is $84 \%$ of the geographical area of the state out of which 3.64 mha i.e. $98 \%$ is under cultivation. It is not bestowed with bounty of natural forests and only $3.9 \%$ of its geographical area is under notified forests.

\section{ROOTCAUSE OF POLLUTION IN HARYANA}

Haryana is fast emerging as one of the most favoured investment destinations in India. The globalization of markets and a buoyant economy have given a tremendous impetus to the industrial sector in Haryana, which already has a competitive advantage in terms of strategic location, basic infrastructure as well as large skilled, educated and young workforce. The State has taken lead in terms of planned industrial and urban growth compared to neighboring States, which has resulted in development of vibrant urban and industrial complexes close to the National Capital. There has been tremendous growth of industries in the towns like Faridabad, Gurgaon, Panipat, Sonepat and Yamunanagar during the last decade. The industries here cause pollution and this emission adversely affects the human health and plant life. They also dump the wastes in the rivers which results in water pollution. Ghaggar River has been affected by such wastes. Recently, the National Human Rights Commission has issued a notice to the state government of Haryana over the heavy pollution in this river. The major cause of the pollution was reported to be the effluents released from the factories and the industries in the area. Another source of pollution in Haryana is the improper waste management in the poultry farms. The animal wastes contaminate the water and air in the surrounding area and have negative effects on the health of the animals and humans. Transportation is the biggest cause of pollution in the state. The number of vehicles in Haryana increase every year. As per statistics, there were 53,77,003 vehicles in the year 2010-11, while $30,87,026$ in 2005-06. This data indicates that in five years the number has nearly doubled. The rise in the use of vehicles increases the pollution level in the air. Some cities in the State are experiencing alarming levels of air pollution. The presence of pollutants in air beyond a certain limits has a detrimental effect on the human health as well as animals. Besides, it also has adverse effect on vegetation.

\section{GROUNDWATER QUALITY IN HARYANA}

There are about 8804 medium and large industrial units working in Haryana, bulk of them are concentrated in six cities namely Ambala, Yamunanagar, Panipat, Sonepat, Gurgaon and Faridabad. The major industries in Ambala are of metal (127) and food processing (46). It is observed that the groundwater occurring at shallow depths is alkaline and is of $\mathrm{NaHCO}_{3}$ type. Some of the well waters have been found with high $\mathrm{NO}_{3}$ due to contamination with domestic sewage. Thermal power plant, Sugar mill, National fertilizer and Panipat Oil refinery are some important units located in and around the Panipat city. There are more than 175 handloom and textile units that use large amounts of chemicals for processing and dyeing of the textile. The groundwater in most part of the nearby area has been polluted due to discharge of effluent either in ponds or cesspools or in the Ganda nala flowing through the city. Gurgaon City has a number of mechanical, electrical, textile, electroplating and chemical industries. The waste generated by these units is dumped untreated either on land or into the city sewage drains. Faridabad and Ballabgarh are major industrial towns and there are about 1500 registered factories housed in these towns, some of them generate hazardous waste. The waste form industries engaged in electroplating works, manufacture of textile, fertilizer, plastic etc., are normally rich in toxic trace metals. Besides, industrial effluent, discharge of untreated sewage in the roadside unlined channels may pollute the ground water due to seepage. Soils in the nearby areas have deteriorated, have turned acidic, due to continuous release of spentwash on the soil during irrigation and mud in the fields by Sugar mills with attached distilleries at Yamunanagar, Panipat and Rohtak. Though waste from hospital and nursing homes are required to be collected separately but, in most cities and towns in the state, such waste form a part of municipal solid waste. The waste is normally dumped in the low-lying areas for natural decomposition. During rainy season, the waste emits foul smell and becomes a potential breeding ground for flies, mosquitoes and other insects. 
Districts of Gurgaon, Bhiwani, Rohtak, Kaithal, Mohindergarh, and Sonepat have more than 30\% of the groundwater with EC above 3000 while EC of groundwater in the districts of Karnal, Kurukshetra, Yamunanagar is below 3000. There are number of places in the south of the state where EC values of groundwater have been found to be more than 10000, making water unpalatable. At some places, such as Farruknagar and Sultanpur, the EC is so high that salt can be manufactured by solar evaporation. 24 percent of wells in Haryana have $\mathrm{F}^{-}$in groundwater outside the maximum permissible range of $1.5 \mathrm{mg} / \mathrm{L}$. In Haryana, small and large parts of almost all districts except districts of Panchkula, Yamunanagar, Ambala, Kurukshetra, Kaithal \& Panipat have groundwater with medium to high fluoride concentration. CGWB during 2001 has found iron in groundwater samples, collected from hydrograph stations ranging from nil to $12.96 \mathrm{mg} / \mathrm{L}$. Majorities of these wells having groundwater with iron above $1.0 \mathrm{mg} / \mathrm{L}$ are located in the districts of Ambala, Yamunanagar, Jind, Sonepat and Hisar.

\section{INTERACTIONS OF SOCIETY AND ENVIRONMENT}

Management of groundwater resources in the Indian context is an extremely complex proposition as it deals with the interactions between the human society and the physical environment. The highly uneven distribution of groundwater availability and its utilization indicates that each situation demands a solution which takes into account the geomorphic set-up, climatic, hydrologic and hydro-geologic settings, groundwater availability, water utilization pattern for various sectors and the socio-economic setup of the region. Socio-environmental sustainability contemplates consideration of society needs and goals, which will vary with time, place and people. The changing nature of sustainability and inter-related risk of resource degradation are the critical considerations while developing plans for the use of nonrenewable water resources. Changing circumstances and increasing knowledge necessitate the periodic review and adjustment of plans designed for the maintenance of well-being of the people while maintaining an equitable inter-generational distribution of benefits. Unplanned depletion of nonrenewable groundwater reserves can undermine and potentially erode the economic and social vitality of any community. Hence, there is need to plan the exploitation of non-renewable groundwater resources and guide their utilization with a view to making communities better prepared socio-economically to cope with increasing water stress as aquifer storage is depleted.

\section{SUSTAINABILITY OF WATER}

The value of water and the importance of having the public recognize the true value of water are of great relevance to the goals of achieving sustainability and efficiency in water supply. Sustainability of water is quite different because it is not preserving but instead reconciling the use of non-renewable water resources with the sustainability of human life. Facilitation of effective social cooperation will be a crucial element in the elaboration and implementation of plans for the utilization of non-renewable water resources. The first challenge in estimating the value of water to the consumer and society is to determine which qualities, amounts, and uses to include. Groundwater resources can never be strictly treated as nonrenewable because it would be available but its potability and replenishment is definitely under human scanner. Potable water and water ecosystem is an essential requirement for the existence of life on earth. Nature has provided water by two means: surface and aquifers. Surface water is depletable and contaminate very easily. Aquifers have a capacity for both water storage and water flow and thus groundwater simultaneously accumulates and circulates.

\section{REDUCING IMPACTS ON HUMAN HEALTH}

Reverse Osmosis System is a process to get rid of all the impurities in drinking water including deadly ions and organisms and pesticide/fertilizer residues but costs vary, depending on the plant capacity and level of utilization, the level of salinity and other impurities in the water and the distance from the source of water. 


\section{DISCUSSION AND RESOURCE STRATEGY}

In Indian context, it is not economically viable to clean aquifers. Technically feasible methods to clean polluted water often do not exist due to highly toxic substances in trade effluents moreover, finding enough freshwater for replenishment is also a problem. For industrial pollution, the issues are of three types: pumping out polluted water from the aquifer; treating this contaminated water to safe limits and replenishing the depleted aquifer with freshwater. Planned and socially-sustainable use of water resources represents a change in policy that will require strengthening social capacity to cooperate in managing common resources through appropriate financial, legal, technical, institutional and political provision. Experience of some water-scarce countries provides valuable lessons on improving the social sustainability of water development and use. Planned Resource Depletion Strategy requires orderly utilization of water reserves, minimizing quality deterioration and maximizing water productivity, with expected benefits and predicted impacts over a specified time-frame. The overall goal should be to use water in a manner that maximizes long-term economic and social development of the community and decreases, over time, the frequency and severity of threats to society, leaving people better prepared to cope with socio-economic stresses associated with increasing water scarcity. A key challenge in the planning process is to determine the quantity of surface and groundwater that can be pumped over the planning period to best serve the communities involved. The planning process should include evaluation of social well-being on a periodic basis, effectiveness of community participation in water regulation and appraisal of the extent to which inter-generational equity is being met.

Modifications to land and groundwater use, as well as accelerated climatic change, can impact the available groundwater resources in quantity and quality sense. Political cost and institutional capacity are the ultimate constraints to surface and groundwater management. Political economies are generally focused more on distributional issues and on short-term objectives (including national food security and rural welfare), rather than on economic efficiency and longer-term issues. Groundwater management plans should be based on effective local institutions, which have the political will and institutional capacity to act. Thus, Water-policy paradigms and water governance need to ensure that water management instruments are politically and institutionally realistic.

\section{CONCLUSION AND POLICY INFERENCES}

It is the ordinary people who raise the alarm about poor water quality. Civil society/institutions need to be strengthened to respond to water quality problems quickly. This is possible through better knowledge and information about the nature of groundwater contamination, potential sources of threats to groundwater quality in their region and degrees of vulnerability, the ill-effects of using contaminated water, and the possible preventive measures. Strengthening civil society institutions is particularly important because groundwater quality variations in nature are often sporadic; it is extremely difficult for monitoring agencies to establish an elaborate network of water monitoring stations due to the high costs and technical manpower involved. Given the absence of complete information about quality of water in various sources, it is also not possible for line agencies to identify appropriate treatment measures. Preventive and curative measures against pollution and contamination of groundwater may continue to receive low priority for years to come and technological measures to prevent the ill effects on human health will get priority in short term. For the long run, policies need to be focused on building scientific capabilities of line agencies concerned with water quality monitoring, water supplies and pollution control; and restructuring them to perform water quality monitoring and enforcement of pollution control norms effectively and to enable them implement environmental management projects.

The successful and facilitating management of groundwater resources requires an institutional set-up which includes consistent policies, legislation, strategic management planning, resource administration capability at government and decentralized levels, an informed and participating surface and groundwater users, capacity for monitoring and assessment, etc. For groundwater management to be 
successful, it is essential, that users' representatives participate, through their groupings or associations, in any decision that might affect their interests.

\section{REFERENCES}

- Calder I.R. 2004, Forests and water - Closing the gap between public and science perceptions, Water and Science Technology, 49(7), 39-53.

- Duarte T.K., Minciardi R., Robba M. and Sacile R. 2015, Optimal control of coastal aquifer pumping towards the sustainability of water supply and salinity, Sustainability of Water Quality and Ecology, 6, 88-100.

- Global Environmental Health, 2007, Research Gaps and Barriers for Providing Sustainable Water, Sanitation and Hygiene Services: Workshop Summary; Institute of Medicine (US) Roundtable on Environmental Health Sciences, Research and Medicine. Washington (DC): National Academies Press (US); 2009.

- Gwenzi W., Dunjana N., Pisa C., Tauro T. and Nyamadzawo G. 2015, Water quality and public health risks associated with roof rainwater harvesting systems for potable supply: Review and perspectives, Sustainability of Water Quality and Ecology, 6, 107-118.

- Jones J.A.A. 2011, Water Sustainability: A Global Perspective, Publisher: Routledge, ISBN: 9781444104882.

- King J.M., Brown C.A. and Sabet H. 2003, A scenario-based holistic approach to environmental water flow assessments for rivers, Rivers Research and Application, 19(5-6), 619-639.

- Micro, Small and Medium Enterprises, 2015-16, State Industrial Profile of Haryana, MSMEDevelopment Institute Government of India, Ministry of MSME 11-A, Industrial Development Colony, Near ITI, Kunjpura Road, KARNAL -132001(Haryana), Website: msmedikarnal.gov.in 